\section{Answering critics can add fuel to controversy}

SIR - Your Editorial " To build bridges, or to burn them" and News Feature "In the name of nature" raise important points about criticism of science and how scientists should best respond (Nature 443, 481 and $498-501 ; 2006)$. The News Feature concerns radical environmentalists and animal-rights activists, but the problem covers a wider area, often involving more enlightened criticism of science from outside the scientific establishment and even, sometimes, from within.

The critics feel passionately that they are right, and that their viewpoints have been unfairly neglected by the establishment. They strike a populist note. They bring into the public arena technical claims that few can properly evaluate. They are sometimes able to generate astonishing amounts of publicity. We all know examples from our own fields or from the media.

Responding to this kind of criticism can be very difficult. It is hard to answer unfair charges of élitism without sounding élitist to non-experts. A direct response may just add fuel to controversies. Critics, who are often prepared to devote immense energies to their efforts, can thrive on the resulting he said, she said' situation.

Scientists in this type of situation would do well to heed the advice in Nature's Editorial. Keep doing what you are doing. And when you have the chance, try to patiently explain why what you are doing is interesting and exciting, and may even be useful one day. Edward Witten Institute for Advanced Study, Einstein Drive, Princeton, New Jersey 08540, USA

\section{Criticism: what to do about science's bad public image?}

SIR - Although you are right to state in your News Feature "In the name of nature" (Nature 443, 498-501; 2006) that environmental activists such as those who fire-bombed a research facility in Olympia, Washington, are misguided, I found your focus on personal flaws and oddities to fall short. Yes, there are many vegan weirdos out there, but some of them are hard-core genetic engineers working in my laboratory. Science and anti-science have a surprising overlap in subculture. (Count the vegetarians at the next Nature office party.) So it's not just subculture that is driving this small, radical and somewhat erratic movement, but a strengthening groundswell of distrust towards science and scientists.

As Nature is a magazine read mostly by scientists, it would be interesting to explore and analyse how we - especially we biologists - managed to become the bad guys. How and why did our public image change from harmless geeks to state- and industry-sponsored evil-doers worthy to be a target? More importantly, what do we do about it? And how do we communicate more effectively what we are doing, why we are doing it and what the opportunities and challenges of modern science are?

So I very much look forward to a follow-up article that won't just have me worried that the friendly tofu-lover I see in one of the Athens clubs tonight will burn down my lab, but will stir me to engage the public in a more effective way. Bor is Striepen Center for Tropical and Emerging Global Diseases, Paul D. Coverdell Center, University of Georgia, Athens, Georgia 30602, USA

\section{Creationists attack secular education in Russia}

SIR - Evolutionary biology has come under attack from creationists in the United States and in several European countries, most recently, Poland ( ${ }^{\alpha}$ Polish scientists fight creationism" Nature 443, 890-891; 2006). Creationists in Russia are also attacking darwinism, and indirectly attacking the principle of a scientifically founded, secular education system.

The Russian case concerns 15-year-old Maria Schreiber and her family, who have filed a complaint to the federal court in St Petersburg demanding a " free choice" for the girl, as her religious sensibilities have been hurt by "Darwin's controversial hypothesis" (reported in Gazeta.ru 27 October 2006). The plaintiffs criticize the biology textbook for classes 10-11 and wish to change it. The court case began on 25 October and may be decided by mid-December.

In Poland, as your News story notes, the creationist case is supported by the minister and deputy minister of education, and the case against evolution has supporters among prominent politicians. In Russia, Schreiber's case has support from the powerful Orthodox church, and the family's lawyers are distant relatives of the last Russian tsar.

As historians of biology and evolutionary biologists, we are aware of the strong tradition in evolutionary biology in Russia, where prominent scholars did important work throughout the twentieth century, particularly in pioneering research into the population genetics of natural populations.

Maybe we are now seeing the delayed effects of 70 years of enforced atheism and official support for darwinism in the Soviet Union, which kept creationism at bay until its collapse in 1991. With the religious freedom that has been allowed since then, numerous churches have become active in Russia: there were 21,664 religious organizations registered by the Ministry of Justice in 2004. Some of them support creationism, and they find an audience that may relate darwinism to Soviet ideology rather than to empirical natural science.

Georgy S. Levit*, Uwe Hoßfeld ${ }^{\star}$, Lennart Olsson $\dagger$ "Ernst-Haeckel-Haus/AG Biologiedidaktik, Friedrich-Schiller-Universităt Jena, Berggasse 7, D- 07745 Jena, Germany

fInstitut für Spezielle Zoologie und

Evolutionsbiologiemit Phyletischem Museum, Friedrich-Schiller-Universitgat Jena, Erbertstraße 1, D-07743 Jena, Germany

\section{Creationism, evolution: nothing has been proved}

SIR — In your News story ${ }^{\alpha}$ Polish scientists fight creationism" (Nature 443, 890-891; 2006), you incorrectly state that I have called for the ${ }^{\alpha}$ inclusion of creationism in Polish biology curricula. As well as being a member of the European Parliament, I am a scientist - a population geneticist with a degree from Oxford University and $\mathrm{ahD}$ from the University of Toronto - and I am critical of the theory of evolution as a scientist, with no religious connotation. It is the media that prefer to consider my comments as religiously inspired, rather than to report my stated position accurately.

Ibelieve that, as a result of media bias, there seems to be total ignorance of new scientific evidence against the theory of evolution. Such evidence includes race formation (microevolution), which is not a small step in macroevolution because it is a step towards a reduction of genetic information and not towards its increase. It also includes formation of geological strata sideways rather than vertically, archaeological and palaeontological evidence that dinosaurs coexisted with humans, a major worldwide catastrophe in historical times, and so on.

We know that information exists in biology, and is transferred over generations through the DNA/RNA/protein system. We do not know its origin, but we know it exists, can be spoiled by mutations, but never improves itself spontaneously. No positive mutations have ever been demonstrated - adaptations to antibiotics or herbicides are equivalent to immunological adaptation to diseases, and not a creation of a new function.

We keep on searching for natural explanations of everything in nature. If we have no explanations we should say so, and not claim that an unproven theory is a fact. Maciej Giertych Institute of Dendrology, Polish Academy of Sciences, 62-035 Kórnik, Poland 